\title{
Arms against a Sea of Troubles: Text and Context of Mikhail Bulgakov's The White Guard
}

\author{
Oleksandr ZABIRKO \\ Research Assistant \\ Institute of Slavic Studies \\ Universität Regensburg, Regensburg (DE) \\ oleksandr.zabirko@ur.de
}

\begin{abstract}
This article focuses on the representation of historical events in literary texts by pointing at the tension between their factual and fictional elements. The fable and the setting of Mikhail Bulgakov's novel The White Guard and his novel-based play The Days of the Turbins serve as examples. Almost one hundred years after its first (incomplete) publication, Bulgakov's novel remains an object of heated debates and is a pivot point for a broad range of current historical, ideological, and cultural clashes between Ukraine and Russia. Against this background, the sophisticated form of Bulgakov's narratives and the author's cult status encourage the reader to consider his works both as historical testimonies and poetic prophecies. More importantly, the historical contextualization of The White Guard and The Days of the Turbins goes far beyond their narrated time and the events of the year 1918: it also includes the ideology of smenovekhoustuo, the dramatic changes in Soviet politics of korenizatsiya and the self-identification of the intelligentsiya in the late Soviet era.
\end{abstract}

Keywords: Mikhail Bulgakov, The White Guard, The Days of the Turbins, Russian Civil War, smenovekhovstvo, korenizatsiya

\section{Résumé}

Cet article est consacré à la représentation d'événements historiques dans des textes littéraires en soulignant la tension entre leurs éléments factuels et fictifs. La fable et le cadre du roman de Mikhaïl Boulgakov La garde blanche et de sa pièce de théâtre Les journées des Turbins servent ici d'exemples. Presque cent ans après sa première publication (incomplète), le roman de Boulgakov demeure l'objet de débats houleux et provoque des affrontements historiques, idéologiques et culturels entre l'Ukraine et la Russie. Dans ce contexte, la forme sophistiquée des récits de Boulgakov ainsi que le statut culte de l'auteur encouragent le lecteur à considérer ses œuvres à la fois comme des témoignages historiques et des prophéties poétiques. Plus encore, la contextualisation historique de La Garde blanche et de Les journées des Turbins va bien au-delà du temps de la narration et des événements de l'année 1918 : elle inclut aussi l'idéologie du smenovekhovstvo, les changements dramatiques dans la politique soviétique de la korenizatsia et l'auto-identification de l’intelligentsia à la fin de l’ère soviétique.

Mots-clés : Mikhail Boulgakov, La garde blanche, Les journées des Turbins, guerre civile russe, smenovekhovstvo, korenizatsia. 


\section{Arms against a Sea of Troubles: Text and Context of Mikhail Bulgakov's The White Guard}

\section{The Red, the White, and the Orange}

On 3 March 2012, the TV channel Rossiya-1 launched a series, The White Guard [Белая Гвардия], directed by Sergey Snezhkin and based on the novel by Mikhail Bulgakov (1891-1940). The series premiere, actively advertised as a "huge" and "long-awaited" cultural event (e.g. Ларина 2012; Богданов 2012), was, in fact, a prelude to a major political event of the year 2012 -the presidential elections in Russia - which would take place only one day later, on 4 March 2012.

Carefully orchestrated by spin-doctors and "political technologists," these elections were intended to provide Vladimir Putin with the necessary legitimacy for his third term as the head of the Russian state. Yet, since the end of 2011, Putin's designated return to Kremlin had been constantly overshadowed by large protest rallies in Moscow, St. Petersburg and other major Russian cities. In the heavily politicised atmosphere of 2012, the TV adaptation of Bulgakov's novel was destined to become a mission of national importance. An elephantine budget and an illustrious cast promised commercial success for the series, while the comments of prominent regime loyalists (such as the writer Aleksandr Prokhanov and the Oscar-winning director Nikita Mikhalkov) on the eve of the premiere were supposed to move the response of the audience in the desired "patriotic" direction. ${ }^{1}$ Capitalising on the aura of Bulgakov as one of the greatest Russian authors of the 20th century, in all of its eight episodes the TV series unequivocally focuses on the ideological subtext of the novel and makes a barely concealed attempt to elaborate an antidote against all sorts of political upheaval (and by extension against any kind of regime change whatsoever).

Set in Kyiv in late 1918, Bulgakov's text effectively counter-balances the revolutionary aspirations of the masses with horrific pictures of violence, destruction, and cultural decay. Steeped in a variety of autobiographical motifs, the novel has been routinely praised for its memory-based literariness, which arguably offers a deep insight into the murderous dynamism of the civil war on the ruins of the collapsing Russian Empire. In 2012 in Russia, however, the

1 These comments were a part of a large discussion during the evening TV show The White Guard. A Foreword [Белая Гвардия. Предисловие] hosted by Vladimir Solov'ëv on Rossiya-1: https://russia.tv/brand/show/ brand id/15445/ (Accessed on 23.08.2019).

CONNEXE 5 | 2019 - Divided Memories, Shared Memories, Poland, Russia, Ukraine: History mirrored in Literature and Cinema 
reminiscences of the revolution and the civil war were firmly connected to the novel's setting in Kyiv, by then the capital of an independent Ukraine, and a city firmly associated with the so-called "Orange Revolution."

Although the metaphor of "Russia's 9/11," coined by Ivan Krastev (2008), may sound today like an over-dramatisation of Ukraine's "colour revolution," one can hardly deny that the peaceful regime change it triggered, definitely had a lasting shock effect on Russia's ruling elite. It was certainly no coincidence that one of the biggest public gatherings of Putin supporters in 2012 was baptised an "AntiOrange Rally." Unsurprisingly, the TV series The White Guard painstakingly portrays Ukraine as a hotbed of all sorts of revolutionary chaos and a place which already due to its geographical and cultural proximity poses a constant threat to the stable political order in Russia.

However, soon after its premiere the TV adaptation of The White Guard received almost unanimously negative reviews both in Ukraine and Russia, mostly due to numerous alterations of Bulgakov's original text (e.g. Богомолов 2012; Бондаренко 2012; Воронцов 2012). The screenplay, written by Marina and Sergey Dyachenko, a duo of prominent fantasy authors from Ukraine, ${ }^{2}$ obviously aims at deliberate exaggeration of some of the most ideologically charged statements made by Bulgakov. For instance, in the novel the leader of the Ukrainian State, Hetman Pavlo Skoropads'kyy, is indeed criticised (and even ridiculed) for his nationalist agenda, but unlike in the series he never calls Russian "a language of dogs." Similarly, while the novel shows the soldiers of the Ukrainian People's Republic as uneducated peasants, the series turns them into a bunch of outright savages who burn schools and fear electric light.

Two years after the premiere, the Ukrainian Culture Ministry decided not to issue distribution licences for the series as they "show contempt for the Ukrainian

2 Being highly successful as fantasy authors, the Dyachenkos write predominantly in Russian, while borrowing extensively from Ukrainian literary tradition (from romanticism to magic realism). The duo of Kyiv-born writers early on began to rely on Russian publishing houses and, increasingly, on a Russian audience, thus their works remain an integral part of the Moscow-centred literary scene, to which the texts of Marina and Sergey Dyachenko contribute with a commercialised form of Ukrainian ethnographic exoticism. An even more important Kyivborn figure behind the scenes of The White Guard was the producer of the series -Aleksandr Rodnyanskiy, who had made a meteoric career in Ukraine in the 1990s (most notably as the creator of $1+1$, the first ever independent television channel in the country) before moving to Moscow in the early 2000s, where he again launched a number of successful cinematographic and television projects. Despite this prominent "Ukrainian" factor, it is not to be denied that The White Guard was produced for a Russian state-owned TV channel, while the cast of the series remained exclusively Russian. Although neither the Dyachenkos nor Rodnyanskiy ever admitted to having produced The White Guard on demand for the Russian ruling elite, in Ukraine the series was heavily criticised even by the most vocally pro-Russian proponents in the Ukrainian political spectrum. Thus, even Oles' Buzina (1969-2015), a Kyiv journalist, who was widely known for his strong pro-Russian position, blasted Rodnyanskiy for "taking Russian state funds and inciting hatred between Ukraine and Russia, to line his pockets by igniting this hellish flame” (Бузина 2012).

CONNEXE 5 | 2019 - Divided Memories, Shared Memories, Poland, Russia, Ukraine: History mirrored in Literature and Cinema 
language, people and the state," and "some facts are distorted to benefit Russia" (Dolgov 2014). This decision, which even made it into the international press, might have remained one of the major scandals between Ukraine and Russia, if not for other events of 2014 -the annexation of Crimea and the Russian military onslaught in Eastern Ukraine. Still, it was exactly the geopolitical turmoil of the year 2014 that fuelled heated debates on and around Bulgakov's novel, showing convincingly that almost one hundred years after its first (incomplete) publication this classic text remains a pivotal point for a broad range of historical, ideological and cultural contestations between the two post-Soviet republics.

While most contemporary commentators either demonise The White Guard for its supposedly chauvinistic and conservative subtext or, on the contrary, commend the novel's "eternal" ethic and aesthetic qualities, in both cases, these interpreters largely ignore the interdependence and interconnectedness of politics and poetics within a literary framed narrative. Literary texts model social and political realities in a way that is fundamentally constituted by aesthetic form. Thus, the writer's narrative choices and his use of aesthetic devices influence the range of possible interpretations in the most profound way.

Against this background, the sophisticated form of Bulgakov's narratives and the author's cult status encourage readers to estimate his oeuvre as a collection of both historical testimonies and poetic prophecies. More importantly, the historical contextualisation of The White Guard and the play based on it, The Days of the Turbins [Дни Турбиных] goes far beyond their narrated time and the events of the year 1918: it also includes the ideology of smenovekhovstvo, the dramatic changes in Soviet politics of korenizatsiya [indigenisation] and the selfidentification of the intelligentsiya in the late Soviet era. ${ }^{3}$

Therefore, it is not surprising that despite their obvious ideological bias, The White Guard, The Days of the Turbins and their movie adaptations are perceived today not only as a fictionalised treatise on the Russian civil war, but also as narrative frameworks for the interpretation of contemporary conflict(s) between Russia and Ukraine.

Already in 2004, a British journalist and author, Misha Glenny, invited his audience to re-read The Days of the Turbins in order "to make sense of the twists in Ukraine's political drama" (i.e. the Orange Revolution of 2004). Using Bulgakov as a guide to Ukraine, Glenny, however, admits that for him Bulgakov's

3 The term korenizatsiya refers to an affirmative Soviet policy towards the non-Russian nationalities in the 1920s (Martin 2001; Suny 2002). The political movement of smenovekhovstvo will be discussed later in this article (for a more detailed account on this movement, see Hardeman 1994).

CONNEXE 5 | 2019 - Divided Memories, Shared Memories, Poland, Russia, Ukraine: History mirrored in Literature and Cinema 
play remains first and foremost a "biting satire of the country's fundamental resistance to rational governance" (Glenny 2010).

Another striking example of the programmatic de-contextualisation of Bulgakov's texts provides an article in the German magazine Die Zeit from March 2014. In the text titled "Pact with the Devil for Ukraine" [Teufelspakt für die Ukraine], the author, Jens Jessen, warns his readership against supporting the pro-European aspirations of the interim Ukrainian government and at the same time advocates the Russian annexation of Crimea. In his rhetoric, Jessen relies on two major sources of inspiration. One of them is the German historian Jörg Baberowski, summarised in the article:

[...] Neither Ukraine nor Belarus nor any other newly established entity was ever supposed to become a sovereign state. The fact that today they act and are widely accepted as such [i.e. as sovereign states] is nothing, but a misinterpretation of the former Soviet nationalities policy (Jessen 2014, 53).

The second voice, "raised" in support of the current Russian geopolitical rampage, is that of Mikhail Bulgakov, whose novel The White Guard, according to Jessen, effectively unveils the devilish nature of Ukrainian nationalism:

Apparently, even for an anti-Communist like Bulgakov, the [Ukrainian] nationalists were worse than the Bolsheviks (who in the novel are even allowed to go to heaven). Does this make the Kyiv-born poet a bad Ukrainian, according to today's understanding? (Ibid.)

Being profoundly rhetorical the above question is obviously asked to make a point rather than to elicit an answer. Nevertheless, this question will serve here as an invitation to look into the novel's text.

\section{In the Heart of the Storm}

The White Guard concerns the life of the Turbin family as the various armies -the Whites, the Reds, the Imperial German Army, and various Ukrainian parties- fight over the city of Kyiv. Historical figures such as Symon Petlyura and Pavlo Skoropads'kyy appear as the Turbin family is caught up in the turbulent effects of the revolution of 1917.

The novel's protagonists belong to the circles of the city's imperial elite. In the army of Hetman Skoropadskyy, they participate in the defence of the city from the forces of the Ukrainian People's Republic (led by Symon Petlyura) in December 1918. Yet, in the civil war between the collapsing Russian Empire's Reds and Whites, they are White, monarchists, on the side of the executed Tsar against both the Bolshevik menace in the north and the Ukrainian national movement 
in their home city. From the novel's opening passage, the political cause of the Turbins is portrayed as lost, yet it is not the fate of the White movement, but that of the family which is the object of author's major concern.

The text's shift of focus from the panoramic to the intimate and from the historical to the private has yet another dimension - a spatial one, where the images of Kyiv (which remains "unnamed" throughout the novel, but is instead referred to as the City) culminate in the detailed descriptions of the house of the Turbins, which is also well-known as the house of the Bulgakov family in Kyiv (today it is preserved and operated as the Mikhail Bulgakov Museum).

Precisely in a way, in which the autobiographical becomes historical, the intimate becomes political. Carefully depicting the City as a Russian-speaking island surrounded by a sea of rebellious Ukrainian peasantry, the narrator additionally emphasises the insular character of the novel's universe by focusing on the home of the Turbins with its cream-coloured curtains, exquisite porcelain, the intermittent playing of classical music, and walls covered with books (Meek 2005). All these details contribute to a solid impression of a cultured enclave in the midst of revolutionary chaos, a refuge of civilisation in the sea of barbarity. By contrast, the Ukrainian national upheaval is presented as follows:

And in those same little towns there were countless teachers, medical orderlies, smallholders, Ukrainian seminarists, whom fate had commissioned as ensigns in the Russian army, healthy sons of the soil with Ukrainian surnames who had become staff-captains -all of them talking Ukrainian, all longing for the Ukraine of their dreams free of Russian landlords and free of Muscovite officers; and thousands of Ukrainian ex-prisoners of war returned from Austrian Galicia. All these plus tens of thousands of peasants could only mean trouble (Bulgakov 1971, 70).

Throughout the course of the novel, the reader is confronted with a stereotypical juxtaposition of Nature vs Culture, where the Ukrainian national movement is conceptualised as a force of nature, while Russian culture, cherished by the Turbins, is not just a national culture like any other, but it is Culture as such.

In terms of their formal aspects, the novel, the theatre play, and their movie adaptations provide a perfect illustration of different artistic forms being applied for the representation of the same historic events. However, in all its artistic incarnations Bulgakov's narrative balances on a fine line between mimesis (as a recognisable representation of reality) and simulation, i.e. a replacement of historical reality with its aestheticised, literary representation. 
Building on a long tradition of realist novels, The White Guard competes with historiography itself in the way it "emplots" facts and events to elaborate a "truthful" sense of historical reality (Harrison 2015, 1). But as a piece of literature equipped with the narrative devices of modernist prose, it often deliberately abandons the mimetic conventions of realism and replaces "reality" with phantasmagorical and utterly fantastic elements. Instead of merely reproducing "historical truth," Bulgakov's text rather reflects on the relation between reality, fiction, and history. The political and ideological messages of the novel may be viewed as a result of this particular reflection.

This is precisely the point where the concept of literary form becomes important. A technical concept of form requires that authors employ those aesthetic devices best suited to realising the intended effects of their respective texts, picking the most appropriate form on the basis of an informed choice from all relevant options. Therefore, the writer's choices of narrated time, plot, point of view, as well as the use of autobiographical details - all these factors are decisive for both representation and interpretation of events and historical figures within a literary text.

Let us take the narrated time as an example. In The White Guard it occupies a period from November 1918 to February 1919, thus despite the numerous flashbacks the novel focuses predominantly on the fall of Hetman Skoropadskyy and the forty-seven days of Petlyura's rule over Kyiv, ascribing all the atrocities of war solely and exclusively to the marauding army of Petlyura and leaving both the Red and the White terrors outside the narrative.

Another important factor is the narrator's point of view. The question "Who is speaking?" is often central for understanding any sort of literary text, but, more importantly, the narrator's perspective effectively signals the status and the unobvious "pretentions" of the text. A typical third-person narration, where a narrator often occupies a godlike position, "naturally" presupposes the narrative's strong claim to objectivity, which potentially triggers the readers' "subliminal" expectation to receive a versatile, all-encompassing account of the events. By contrast, the first-person narration or narration from the point of view of a single character is far more subjective, simply because one person has limited mobility and cannot read the minds of other characters. In The White Guard, the classical third person narration dominates, but this conventional mode is frequently broken by the author's recourse to so-called "free indirect speech" (French: discours indirect libre), which can be described as a "technique of presenting a character's voice partly mediated by the voice of the narrator" (Stevenson 1992, 32). A good 
illustration is the episode of the assassination of a Jew by a Ukrainian military patrol: Being asked to show his papers, a Jew, Yakov Feldman, accidentally shows a pass signed and sealed by the White General and is immediately killed by the Ukrainian sergeant Galanba. This is how this episode is being narrated in the novel (Булгаков 2015, 116, English translation from Bulgakov 1971, 129):

$\mathrm{Ax}$, Боже мой, Боже мой! Что ж он наделал? Что вы, Яков Григорьевич, вытащили? Да разве вспомнишь такую мелочь, выбегая из дому, когда из спальни жены раздастся первый стон? О, горе Фельдману!

Oh my God, what have I done? Why did he have to choose that piece of paper? But how could he be expected to remember, when he has just run out of doors, when his wife is in labor? Woe to Feldman!

Who is speaking here? In the first sentence ("Oh my God, what have I done?") it is most likely Feldman, i.e. a literary character, in the second ("Why did he have to choose that piece of paper?") - the narrator, then in the Russian original it is the narrator again, who is addressing Feldman directly ("Что вы, Яков Григорьевич, вытащили?”), an important sentence which remains rather unclear in the English translation by Michael Glenny; and finally in the fourth sentence (“Да разве вспомнишь такую мелочь...") we have an assessment of the entire episode, where we cannot be entirely sure whether it is the narrator or Feldman himself who is commenting on the situation. We cannot attribute this assessment to anybody, since already in the fourth sentence we are not able to identify the speaker - the voice of the narrator effectively merges with that of the literary character and becomes indistinguishable. ${ }^{4}$

Functioning as a purely aesthetic element, this polyphonic technique becomes much more problematic, when applied to the narration of historical events. Consider the following example:

Вильгельм. Вильгельм. Вчера убили трех немцев. Боже, немцы уходят, вы знаете?! Троцкого арестовали рабочие в Москве!!! Сукины сыны какието остановили поезд под Бородянкой и начисто его ограбили. Петлюра послал посольство в Париж. Опять Вильгельм. Черные сингалезы в Одессе. Неизвестное таинственное имя -консул Энно. Одесса. Одесса. Генерал Деникин. Опять Вильгельм. Немцы уйдут, французы придут. (...) Петлюра послал посольство к большевикам. Это еще лучше штука. Петлюра. Петлюра. Петлюра. Петлюра. Пэтурра... (Булгаков 2015, 68-69).

Wilhelm. Three Germans murdered yesterday. Oh God, the Germans are leaving -have you heard? The workers have arrested Trotsky in Moscow!! Some sons of bitches held up a train near Borodyanka and stripped it clean. Petlyura has sent

4 This is true for the Russian original sentence “Да разве вспомнишь такую мелочь...” (literally, "Ноw can one be expected to remember..."), whereas in the English translation ("But how could he be expected to remember...") the translator already by using the pronoun "he" attributes this sentence to the narrator.

CONNEXE 5 | 2019 - Divided Memories, Shared Memories, Poland, Russia, Ukraine: History mirrored in Literature and Cinema 
an embassy to Paris. Wilhelm again. Black Senegalese in Odessa. A mysterious, unknown name -Consul Enno. Odessa. General Denikin. Wilhelm again. The Germans are leaving, the French are coming. (...) Petlyura has sent a mission to the Bolsheviks. That's an even better joke. Petlyura. Petlyura. Petlurra... (Bulgakov 1971, 74).

We cannot learn from the above passage what the Germans or the French are doing, what Denikin's or Petlyura's agenda is; we cannot distinguish facts from rumours, but we can virtually breathe the atmosphere of revolutionary turmoil epitomised in the overarching metaphor of a blizzard. Indeed, as the novel's readers, we find ourselves in the very middle of a snowstorm, where there is a lot of movement around, but where we can never get the whole picture of what is going on. All the figures and the events appear distorted and obfuscated. It is exactly the polyphony and the polyvalence of the narrative that make The White Guard a literary masterpiece on the one hand and an unreliable historiographical account on the other.

Bulgakov's narrative techniques were neither very innovative nor can they serve as evidence for the author's deliberate distortion of "historical truth." In fact, Bulgakov's text adheres to the classic Aristotelian discrimination, i.e. History is about the recording of facts whereas Poetry is about the possibility of facts happening. Thus, The White Guard may be said to render its own "poetic truth" (Schiller's poetische Wahrheit), which implies that a literary representation of the events should simply convince regarding their verisimilitude and should not verify or comment on the facts, as precisely the scholarly historical narration has to do.

Being rather simple in theory, this discrimination, however, proves to be complicated in terms of literary practice. In The White Guard, this complexity becomes especially evident when the novel's documentary motifs (i.e. the exaggerated exactness of topographical details, the painstaking descriptions of military units and finally the naturalistic panorama of upper-class Kyiv in 1918) intertwine with utterly fantastic symbols, rumours and phantasmagorical images of the imminent Apocalypse.

Starting from the novel's opening line "Great and terrible was the year of Our Lord 1918, of the Revolution the second," Bulgakov's style persistently keys to the Book of Revelations, thus constructing a peculiar narrative that swings between a historical chronicle and a prophecy. This tension, which the author upholds throughout the entire course of the novel, makes it possible to read The White Guard from two seemingly incompatible perspectives, i.e. as a careful 
documentary and (at the same time) as a prophetic text that conveys poetic messages of transtemporal validity.

Paradoxically, it is the politics that keeps these two perspectives together, since the novel's surreal and fantastic elements culminate in a description of a very political character - Symon Petlyura, who appears as a satanic figure in more than just a metaphorical sense. The military leader of the Ukrainian People's Republic is the devil himself - a faceless character with obscure biography, who may simultaneously appear in different places and who is described with all the satanic paraphernalia (e.g. as a prisoner he was held in cell No. 666). Yet, precisely when the narrative's pendulum is highest in its swing from the historical to the fantastic, we learn that is was: "All nonsense, of course. There was no such man. Rubbish, mere legend, a pure mirage" (Bulgakov 1971, 70).

Needless to say, The White Guard is more than a pamphlet against Petlyura -it cannot and should not be reduced to any simple-minded political message. Countless Bulgakov fans would eagerly testify that this book is about "eternal values": It manifests the triumph of high culture over ideology and provides an emotional narrative about the sacred spaces of home and family, which appear as far more important than political splits and quarrels. ${ }^{5}$ Finally, The White Guard is about moral principles and the righteous code of conduct in a turbulent time of treachery, doubt, and rumours. This is a classical, canonical interpretation of the novel, which is not to be argued against -to be sure, all those motifs are there in the text and make The White Guard great literature.

Yet they are not the reason why the movie adaption of the novel became a part of Putin's election and they do not explain how and why Bulgakov's text may be applied in the legitimation of the current Russian aggression against Ukraine.

\section{The Masks of Evil}

The obvious reason why an unequivocally political reading of The White Guard is possible is that at its core this great work of literature remains deeply and profoundly colonial. Although this simple observation may still sound like a sort of heresy in Bulgakov studies, it is obvious that in most Russian and Western treatises on The White Guard the various Ukrainian parties and forces from 1918 are referred to simply as "nationalists" (Curtis 2017, 42; Glenny 2010), despite their very different political and ideological goals.

5 On the other side of ideological barricades very similar ideas were articulated by Mikhail Sholokhov in his prominent novel And Quiet Flows the Don [Тихий Дон] (1928). Like The White Guard, Sholokhov's "red" novel provides ethical grounds for the reconciliation of former enemies.

CONNEXE 5 | 2019 - Divided Memories, Shared Memories, Poland, Russia, Ukraine: History mirrored in Literature and Cinema 
However, the colonial perspective does not result from the way in which various Ukrainian forces are treated in the novel, and nor from the fact that the Turbin family, so warmly and tenderly described, remains unquestioningly loyal to imperial Russia. The colonial perspective results from the plot itself: The spatial sphere of the novel, i.e. the sphere where the protagonists act, shrinks here into the hermetic space of House No. 13 and is therefore reduced to a small community of friends and relatives. Without leaving their own house, the Turbins all of a sudden find themselves in a foreign country -they don't speak the language, they are perplexed by the existence of the local culture and they have very little understanding for the political agenda of the natives. Thus, the loss of home, as the real tragedy of the Turbin family, has a double nature - not only the Russian Empire as their political homeland ceases to exist, more importantly, Kyiv as "the mother of all Russian cities" (Булгаков 2015, 21, 112) and as the City (as such) suddenly loses its cosiness and turns into an utterly hostile and foreign environment.

The bitterness at a great city being overwhelmed by revolutionary upheaval prompts the narrator to treat all the parties, including the Whites, with a merciless criticism:

And whenever there came vague rumours of events from that mysterious place called "the country," rumours that the Germans were robbing the peasants, punishing them mercilessly and mowing them down by machine-gun fire, not only was not a single indignant voice raised in defence of the Ukrainian peasants but, under silken lampshades in drawing-rooms, they would bare their teeth in a wolfish grin and mutter: "Serve them right!" (Bulgakov 1971, 62).

Following James Meek (2005), one is inclined to discover in The White Guard "a powerful sense of an irresistible, unearthly force about to punish a city for its corruption, selfishness, and vanities." Foreshadowing Bulgakov's magnum opus The Master and Margarita [Мастер и Маргарита], this particular kind of "poetic truth" seems to provide an almost universal model for conceptualising the "inverted" world of post-revolutionary Russia: In The Master and Margarita it is Voland (i.e. Satan) punishing the Moscow of the 1930s; in The White Guard, it is Petlyura and ultimately the Reds punishing the Kyiv of 1918.

Yet, in a world where the sides have sides, even evil has two very different faces. While in The White Guard the Ukrainian national movement is led by the devil himself, the Bolsheviks play here a somewhat different, Mephistophelian role -they truly are a "part of that power which would the Evil ever do, and ever does the Good."'

6 Faust, transl. George Madison Priest. In the novel Goethe's "Faust" is mentioned no less than eight times.

CONNEXE 5 | 2019 - Divided Memories, Shared Memories, Poland, Russia, Ukraine: History mirrored in Literature and Cinema 
From the point of view of the novel's protagonists, it is not to be denied that the Bolsheviks bring order and peace to the City, but more importantly, they preserve the Russian empire, which was collapsing under the Turbins' very eyes. The latter achievement is of course not part of the novel itself, but it is definitely a part of its turbulent publication history.

\section{Changing the Signposts}

This history is loosely connected to the ideology of smenovekhovstvo -a political movement that emerged in the Russian émigré community soon after the publication of the magazine Smena Vekh [Change of Signpost] in Prague in 1921. The members of the movement (smenovekhovtsy) promoted the idea of reconciliation between the Reds and the Whites as well as the idea of accepting the Soviet regime and the October Revolution as a natural and popular progression of Russia's fate, something which was not to be resisted despite the ideological incompatibilities with Marxism and Leninism. In Soviet Russia, at the beginning of the 1920s, the movement was not officially recognizsed, but de facto tolerated.

The first thirteen chapters of the novel The White Guard were published during the year 1925 in the magazine Rossiya - a mouthpiece of smenovekhovtsy in Russia. But already in May 1926, Isayya Lezhnëv -the chief editor of the magazine- was arrested and expelled from the country; the magazine itself was closed down by the Soviet authorities (Чудакова 1988, 333-334). At that time Bulgakov attracted some serious attention from the Soviet secret police OGPU. On 7 May 1926, his house in Moscow was searched: Several documents, including the diary and the first handwritten version of the novel The Heart of a Dog [Собачье сердце], were confiscated (Ibid). Due to these events, the further publication of The White Guard in Soviet Russia became impossible.

Instead, Bulgakov was invited to write a version for the stage. The play was titled The Days of the Turbins and was premiered at the Moscow Art Theatre in 1926 to great acclaim, soon becoming a part of what was known as the theatre's major repertoire. In the final version of the play (which was strongly influenced by Soviet censors), Bulgakov addresses the audience with a fairly simple message that Soviet rule at least gives the former White officers a chance to virtually "make Russia great again." This subliminal idea comes to light in the last act of the play, in which the bitterly disillusioned White officers declare their readiness to join the ranks of the Red Army:

Myshlayevsky: [...] At least they'll know that I'll be serving in a Russian army. The people are not with us. They are against us.

CONNEXE 5 | 2019 - Divided Memories, Shared Memories, Poland, Russia, Ukraine: History mirrored in Literature and Cinema 
Studzinsky: [...] We used to have Russia - a great power!

Myshlayevsky: And we shall have again. Of course, we shall! (Bulgakov 1979, 344345).

From this perspective, cooperation with the Bolsheviks appears not as an act of treachery but in fact as a sign of true patriotism. The audience response to this particular message was rather mixed. Two prominent examples are, however, of special interest. One of them comes from Walter Benjamin, a German philosopher and literary critic, who visited Moscow in December 1926 and attended the play in the Art Theatre. In his diary, Benjamin calls Bulgakov's drama a "revolting provocation":

Especially the last act, in which the White Guards "convert" to the Bolsheviks, is just as tasteless in terms of the dramatic fable as it is false in the idea. [...] Whether this last act was added by the censors [...] or was originally there is irrelevant for the overall assessment of the play (Benjamin 1980, 35-36).

A quite opposite interpretation of the same episode and of the same political message was provided by another prominent commentator, Joseph Stalin, who wrote a letter to Vladimir Bill'-Belotserkovskiy dated 2 February 1929:

The disgraceful portrayal of Ukrainians [in the play] has its scandalous side, but there is also another side to it... The play does more good than harm. Mind you, the general impression which the viewer leaves the theatre with is that of the Bolsheviks' victory. That the likes of the Turbins decide to lay down the arms and succumb to the will of the people, conceding the defeat, could mean only one thing: that the Bolsheviks are invincible" (Popovich 1995, 53).

Note, that it is precisely the same line of argument that Stalin would apply ten days later (on 12 February 1929) during his meeting with a delegation of Ukrainian writers:

Take, for example, this very well-known Bulgakov and his Days of the Turbins. Of course, he is not one of us. His way of thinking can hardly be called Soviet. But with his Turbins, he definitely did us a lot of good (Юмашева 1991, 136-137).7

This assessment provoked a harsh response from Stalin's Ukrainian guests, who took great offence, both as Soviets and Ukrainians, and they spent most of their meeting with Stalin heavily criticising Bulgakov's play for its imperial subtext. For instance, the young novelist Oleksa Desnyak made the following statement:

When I saw The Days of the Turbins, my first impression was that Bolshevism defeats those people, not because it is Bolshevism, but because it preserves a single,

7 In the Russian original: "Или взять, например, этого самого всем известного Булгакова, если взять его “Дни Турбиных.” Чужой он человек, безусловно. Едва ли он советского образа мысли. Однако своими Турбиными он принес все-таки большую пользу безусловно.”

CONNEXE 5 | 2019 - Divided Memories, Shared Memories, Poland, Russia, Ukraine: History mirrored in Literature and Cinema 
great and indivisible Russia. This concept is all too evident here, and such victory of Bolshevism is something we do not need (Ibid). ${ }^{8}$

As Mayhill Fowler (Fowler 2015, 275) rightly highlights, many of these Ukrainian writers had fought in the Red Army and, unlike Bulgakov, considered themselves loyal and true Communists. It is not surprising, therefore, that Bulgakov's depiction of the revolution in Kyiv offended them because it ignored their own story of loyalty to Soviet communism and to Ukraine. They were offended, moreover, as Ukrainians, expressing shock at how the Moscow Art actors presented the German characters with a flawless German accent but caricatured the Ukrainian accent for laughs (Ibid.).

Furthermore, their attitude towards Bulgakov's play was largely a product of the so-called Literary Discussion, which facilitated a fairly new understanding of Ukrainian national identity, freed from ethnic and folkloristic obstinacy, and open both to the European ideas of cosmopolitism and the Soviet notion of the cultural avant-garde. Initiated by the novelist Mykola Khvyl'ovyy in the early 1920s, this wide-ranging debate on the national status of Ukrainian culture coincided with the implementation of korenizatsiya - an affirmative Soviet policy towards the non-Russian nationalities. Although the main idea of korenizatsiya was to form communist cadres for every nationality (and every Soviet republic), in Ukraine this policy helped to raise the literacy of the Ukrainian-speaking rural population, while stimulating an unprecedented development of Ukrainian print media and literary production.

Borrowing extensively from European traditions, the avant-garde of Ukrainian literature of the 1920s seized an opportunity to define their identity distinct from their Polish and Russian counterparts. Although we find no evidence of Bulgakov taking any part in discussions dealing directly with the Ukrainian cultural Renaissance, in Ukrainian literary circles he quickly acquired a reputation as a Russian imperialist. Already in the sketch The City of Куіv [Киев-город], published in 1923 in the newspaper Nakanune [On the Eve], Bulgakov admits that even the signboards written in Ukrainian remind him of the disastrous ruins caused by the war (Popovich 1995, 52). Lacking any knowledge of the Ukrainian language he denounces its use in Kyiv's public life. In another part of the sketch, subtitled "Science, Literature and Art," Bulgakov dismisses their existence in the post-revolutionary, "Ukrainianised" Kyiv with the single word: "net" (there is no

8 In the Russian original: “Десняк. Когда я смотрел “Дни Турбиных,” мне прежде всего бросилось то, что большевизм побеждает этих людей не потому, что он есть большевизм, а потому, что делает единую великую неделимую Россию. Это концепция, которая бросается всем в глаза, и такой победы большевизма лучше не надо.”

CONNEXE 5 | 2019 - Divided Memories, Shared Memories, Poland, Russia, Ukraine: History mirrored in Literature and Cinema 
such thing). The sketch ends with a strong and scornful condemnation of Symon Petlyura. After 1924 Bulgakov ceased visiting his native city.

It was just at the time the Literary Discussion was at a high point in its struggle to implement the new national policy and a new, modernised vision of Ukrainian culture that The Days of the Turbins was first staged at the Moscow Art Theatre. Portraying Ukrainians as the common enemy of both the Reds and the Whites, Bulgakov's play addresses the complex problem of nationalities by, as Colin Wright puts it, "throwing down the gauntlet at the most painful problems his contemporary Ukrainians were undergoing in the establishment of their political and cultural sovereignty" (Wright 1978, 68).

The most refined response to Bulgakov's play was given by the dramatist Mykola Kulish, who produced his three major plays as a direct reply to Bulgakov's messianic views of Russian cultural supremacy. In his play Myna Mazaylo [Мина Мазайло] (1929), Kulish introduces the proverbial figure of Aunt Motya [Тьотя Мотя] - a narrow-minded market woman from Kursk who, being a declared fan of The Days of the Turbins, acts as a parody of Bulgakov's views on Ukrainian culture and national identity.

While Kulish's dispute with Bulgakov remained within the framework of literary production, other writers did not shy away from using backstage politics, while pressing for an official ban on Bulgakov's play - a wish they expressed directly during their conversation with Stalin in 1929.

The Repertory Committee (the Soviet theatre licensing body) issued such a ban. We can speculate about Stalin's motives that led to this decision. There is a theory that Bulgakov and his play were just a pawn sacrifice that secured the support of the Ukrainian Communists for Stalin in his campaign against the socalled Right Opposition, led by Bukharin (Юмашева 1991, 140). In any case, for Bulgakov, the decision to ban The Days of the Turbins was his personal tragedy, which brought him to the verge of ruin and a nervous breakdown. He remained officially outcast and professionally shunned. Out of despair he even addressed a plea to the Soviet government to let him emigrate. Obviously, he did not hope to receive any answer, yet unexpectedly a direct reply came in 1932 in the form of a telephone call from Stalin himself.

A lot has been said and written about Stalin's legendary telephone conversation with Bulgakov as well as the dictator's personal interference, which led to the restart of the production of The Days of the Turbins and, arguably, saved Bulgakov's life in the years of the Great Purge (e.g. Smeliansky 1993, 170-173; Elagin 1951, 102-103; Чудакова 1988, 311f.). But from the Ukrainian perspective, it seems 
justified to reflect not on the complicated relationship between a Poet and a Despot, but rather to view Bulgakov's case in the light of the korenizatsiya campaign and its abrupt ending, as well as post-Stalinist cultural politics. Reversing the perspective from Russian literature to Soviet-Ukrainian politics, one will have to admit that 1932 was a very special year in the history of Ukraine: it was a year in which the unruly Ukrainian peasantry was literally dying out (in what would later be known as the Great Famine or Holodomor of 1932-1933), the Ukrainian Party leadership was being "purged" and Ukraine's cultural renaissance was about to become the "Executed Renaissance." Against this backdrop, the triumphant comeback of The Days of the Turbins, which in 1932 quickly became a massive box-office hit in Moscow, takes on additional connotations (probably unintended by the author, but nonetheless evident for the viewers and readers of his play). Precisely at the time the Ukrainian Soviet Republic was being forced back to the state of an imperial province, on stage the White Guards' reconciliation with the winners of the civil war was being enacted as an agreement made largely at the expense of other losers.

\section{The Long Echo of the Civil War}

Unlike the play, which continued to run in Moscow until June 1941 (i.e. until the German assault on the Soviet Union), the novel it is based on needed decades to make its way to readers. Bulgakov's widow had The White Guard published in large part in the literary journal Moskva [Moscow] only in 1966, at the end of the Khrushchev era. This publication was sensational both in terms of its success and its impact on the literary process since the form and the style of the novel were worlds away from the officially endorsed aesthetics of socialist realism. Moreover, while purified from some of its most disparaging anti-Ukrainian remarks, this publication marked a quite but steady movement towards the rehabilitation of the Whites and, by extension, pre-revolutionary, imperial Russia. In the heyday of the Soviet political system such rehabilitation could not be ideological -it was instead purely aesthetic. The noble titles, the manners, and the language of the elites -all these elements returned to the public sphere as a part of Russian national heritage despite their ideological incompatibility with Soviet cultural doctrine.

The movie adaptation of The Days of the Turbins directed by Vladimir Basov was released in the Soviet Union in 1976 and was another huge success, but already in the late 1960s the Soviet audiences were applauding films like The Adjutant of His Excellency [Адъютант его превосходительства] and The Crown of the Russian Empire [Корона Российской империи], in which the boundary between politics and aesthetics becomes permeable and the foes of the Bolsheviks appear 
as ideologically flawed but likeable Russian patriots. Against this background both The White Guard and The Days of the Turbins may be viewed as trendsetters for imperial nostalgia, which was echoed in the films like The Russia We Lost [Россия, которую мы потеряли] (1992) by Stanislav Govorukhin or, more recently, Russian Ark [Русский ковчег] (2003) by Aleksandr Sokurov.

Apart from the inspiring nostalgia for lost imperial grandeur, the Turbins effectively presented a new form of imaginary self-identification for readers in the intelligentsia in the late USSR, offering them a viable model of being in its own way both anti-totalitarian and anti-democratic. Within this model, the attitude of cultural superiority culminates in an elitist identification not with a colonised subject but with a coloniser - a bearer of the high culture in the backward society of the natives.

Unsurprisingly, the attitude towards these tendencies in Kyiv (in the heart of the former imperial province) and Moscow (the former imperial centre) was in many ways different. While in Russia the cult status of Bulgakov has remained unshakeable at least since the late 1960s, in Ukraine after 1991 Bulgakov's literary persona has provoked rather mixed reactions, ranging from deep veneration of the Kyiv-born classic author to vehement rejection of his literary legacy as a sort of unwanted heritage. One of the most recent attacks on this heritage was launched by Oksana Zabuzhko, a prominent Ukrainian poet and novelist, who, denouncing Bulgakov as a Russian chauvinist, demanded "the cultural restitution" of the Bulgakov Museum in Kyiv, which she thought should have received the name of one of its real owners -the Ukrainian engineer Vasyl' Lystovnychyy, who in The White Guard is portrayed as the greedy, despicable landlord Vasiliy Lisovich (Забужко 2015). According to Zabuzhko, this portrayal is already an outrageous act of character defamation by Bulgakov (Ibid.).

Having sparked a heated discussion, Zabuzhko's initiative so far remains unrealised, and traces of it can be found only on the Ukrainian Wikipedia page of the Museum, where the edifice in question is referred to as Lystovnychyy House. While in Ukraine Bulgakov's oeuvre seems to be firmly connected to the obsessive search for "historical truth" (and, by extension, for "historically justified" revenge), in today's Russia, on the contrary, the fiction seemingly prevails over any kind of historical reality. Thus, in the Russian Wikipedia, the very same house features as Dom Turbinykh - the House of the Turbins... 


\section{Bibliographical references}

Benjamin, Walter. 1980. Moskauer Tagebuch. Frankfurt am Main: Suhrkamp.

Bulgakov, Mikhail.1971. The White Guard. London: Collins and Harvill Press.

Bulgakov, Mikhail. 1979. "The Days of the Turbins.” In Classic Soviet Plays, edited by Alla Mikhailova, 265-359. Moscow: Progress Publishers.

Curtis, Julie. 2017. Mikhail Bulgakov. London: Reaktion Books.

Dolgov, Anna. 29.07.2014. "Ukraine Bans Russian Films for Distorting Historical Facts.” The Moscow Times. https://www.themoscowtimes.com/2014/07/29/ukraine-bans-russian-films-fordistorting-historical-facts-a37767

Elagin, Iurii. 1951. Taming of the Arts. New York: E. P. Dutton.

Fowler, Mayhill C. 2015. "Mikhail Bulgakov, Mykola Kulish, and Soviet Theater: How Internal Transnationalism Remade Center and Periphery." Kritika: Explorations in Russian and Eurasian History 16 (2): 263-290.

Glenny, Misha. 11.02.2010. "Bulgakov is once again our guide to Ukraine." Financial Times. https://www.ft.com/content/e2e9f91a-1740-11df-94f6-00144feab49a.

Hardeman, Hilda. 1994. Coming to Terms with the Soviet Regime. The "Changing Signposts" Movement among Russian Émigrés in the Early 1920s. Dekalb: Northern Illinois University Press.

Harrison, Christine, and Angeliki Spiropoulou. 2015. "Introduction: History and Contemporary Literature.” Synthesis: an Anglophone Journal of Comparative Literary Studies 8: 1-13.

Jessen, Jens. 2014. “Teufelspakt fur die Ukraine.” Die Zeit 14: 53.

Krastev, Ivan. 2008. The crisis of the post-Cold War European order. https://www.eurozine.com/ the-crisis-of-the-post-cold-war-european-order/.

Martin, Terry D. 2001. The Affirmative Action Empire: Nations and Nationalism in the Soviet Union, 1923-1939. Ithaca, NY: Cornell University Press.

Meek, James. 2005. Pockets of resistance, 2005. https://www.theguardian.com/books/2005/ jun/25/featuresreviews.guardianreview29.

Popovich, Maria. 1995. "The Days of the Turbins by Mikhail Bulgakov in the Light of the Russian-Ukrainian Literary Discussion.” In Bulgakov: The Novelist-Playwright, edited by Lesley Milne, 63-76. Luxembourg: Harwood Academic Publ.

Smeliansky, Anatoly. 1993. Is Comrade Bulgakov Dead? Mikhail Bulgakov at the Moscow Art Theater. New York: Routledge.

Stevenson, Randall. 1992. Modernist Fiction. Lexington: University of Kentucky.

Suny, Ronald, and Terry Martin (eds). 2002. A State of Nations: Empire and Nation-Making in the Age of Lenin and Stalin. New York: Oxford University Press.

Wright, Colin. 1978. Mikhail Bulgakov. Life and Interpretations. Toronto: University of Toronto Press.

Богданов, Валентин. 02.03.2012. “Булгаковская Белая Гвардия снова на коне: большая премьера на телеканале ‘Россия.” Вести.Py. https://www.vesti.ru/doc.html?id=731547.

CONNEXE 5 | 2019 - Divided Memories, Shared Memories, Poland, Russia, Ukraine: History mirrored in Literature and Cinema 
Богомолов, Юрий. 06.03.2012. “Мосты над безднами.” Российская Газета. https:// rg.ru/2012/03/06/Богомолов.html.

Бондаренко, Владимир. 14.03.2012. “Провал Белой Гвардии.” Киевский Телеграф. http:// www.telegrafua.com/social/12844/.

Бузина, Олесь. 30.03.2012. “Белогвардейцы-самозванцы в восьми скучных сериях.” Сегодня.https://www.segodnya.ua/lifestyle/showbiz/ictorii-olecja-buziny-belohvardejtsycamozvantsy-v-vocmi-ckuchnykh-cerijakh-295055.html.

Булгаков, Михаил. 2015. Белая Гвардия. Москва: Ладомир.

Воронцов, Андрей. 2012. “У холодного очага Турбиных.” Литературная Газета 9 (6360). https://gzz.ru/article/N9--6360---2012-03-07-/U-holodnogo-ochaga-Turbinbh18483/.

Забужко, Оксана. 18.06.2015. “Этот проклятый “квартирный вопрос.” http://www. radiosvoboda.org/content/article/27079412.html.

Ларина, Юлия. 2012. “Окаянные дни Турбиных.” Огонёк 8: 43. https://www.kommersant.ru/ doc/1877683.

Чудакова, Мариэтта. 1988. Жизнеописание Михаила Булгакова. Москва: Книга.

Юмашева, Ольга, и Илья Лепихов. 1991.“И.В. Сталин: краткий курс советского театра.” Искусство кино 5: 132-140. 